\title{
The effects of probiotics on the performance, egg quality and blood parameters of laying hens: A meta-analysis
}

\author{
O. Sjofjan ${ }^{1,2,6}$, D.N. Adli ${ }^{1,2}$, M.M. Sholikin ${ }^{2,3}$, A. Jayanegara ${ }^{2,4}$ and A. Irawan ${ }^{2,5}$ \\ ${ }^{1}$ University of Brawijaya, Faculty of Animal Science, Department of Nutrition and Feed Technology, Malang 65145, Indonesia \\ IPB University, Faculty of Animal Science, \\ ${ }^{2}$ Animal Feed and Nutrition Modelling (AFENUE) Research Group, \\ ${ }^{3}$ Department of Nutrition and Feed Technology, Graduate School, \\ ${ }^{4}$ Department of Nutrition and Feed Technology, \\ Bogor, West Java, 16680, Indonesia \\ ${ }^{5}$ Sebelas Maret University, Surakarta 57126, Indonesia
}

KEY WORDS: egg production, intestinal absorption, microorganisms, mix models, systematic reviews

Received: 13 January 2021

Revised: 14 February 2021

Accepted: 17 February 2021

${ }^{6}$ Corresponding author:

e-mail: osofjan@yahoo.com

\begin{abstract}
A meta-analysis was conducted to determine the effects of probiotics on the performance, egg quality and blood parameters in laying hens. A database was designed based on published papers reporting the use of probiotics in laying hens. Articles were rigorously selected according to the Systematic Review Centre for Laboratory Animal Experimentation (SYRCLE) protocols. The final database consisted of 47 in vivo studies with 190 treatment units. The statistical meta-analysis was performed according to the linear mixed models by using $R$ software version 3.6.3. It was shown that dietary addition of probiotics linearly increased $(P<0.001)$ egg production and concomitantly decreased $(P<0.01)$ feed egg ratio (FER) with a linear pattern. Egg mass and feed intake were not associated with the probiotic treatment. Concerning egg quality parameters, probiotics did not affect egg weight but increased eggshell thickness $(P<0.001)$, eggshell weight $(P<0.01)$ and yolk colour $(P<0.01)$. Probiotics reduced $(P<0.05)$ cholesterol and low-density lipoprotein cholesterol while elevated $(P<0.05)$ high-density lipoprotein cholesterol blood concentrations. In conclusion, poultry products with health-promoting properties can be obtained with the use of probiotics which positively affect production performance, egg quality and blood metabolites parameters in lying hens.
\end{abstract}

\section{Introduction}

Microorganisms with beneficial properties, as Lactobacillus strain, were firstly used in animal feeding in the early 1900s in the Caucasus Mountains (Markowiak and Śliżewska, 2018). During extensive investigations they were further named probiotics and their multiple positive effects primarily in maintaining intestinal integrity and gut health, improving nutrient digestibility and production performance in most animal species were observed. Genera of microorganisms commonly used as probiotics in animals include Bifidobacterium, Lactococcus, Lactobacillus, Bacillus, Streptococcus and yeasts. The development of probiotics use commenced when sub-therapeutic levels of antibiotics began to be banned for livestock in 1996 in Germany and Denmark (Maron et al., 2013). The European Union introduced probiotics as an alternative to antibiotics and this has subsequently become an area of great interest for researchers worldwide. In 1997, antibiotic growth promoters (AGPs) 
continued to be banned including the use of tylosin, spiramycin, bacitracin, virginiamycin, carbadox and olaquindox in the Netherlands. In 2005, Taiwan announced a ban on the use of such drugs in the livestock (Maron et al., 2013).

The ban for using AGPs has been extended to developing countries, with Indonesia being the last of them (ban introduced in 2018). The most recent Indonesia regulation states that it is no longer acceptable to use AGPs in animal production including laying hens. Research on the use of probiotics in laying hens has been widely conducted worldwide and published in various scientific journals. The number of publications in Scopus on this topic increased from less than 50 in 1995 to more than 250 in 2015 (Park et al., 2016a). However, this increase in publications number was not matched by consistent trial results. Yörük et al. (2004) reported that probiotics had no consistent effects on egg quality parameters. In other studies (Kurtoglu et al., 2004; Forte et al., 2016; Abd El-Hack et al., 2017; Mikulski et al., 2020) it was reported that probiotics consistently increased egg quality parameters.

Such results inconsistency generated from different studies may be mediated by employing a metaanalysis method. Meta-analysis is a term that refers to a quantitative and systematic approach which forms a continuous analysis of existing research (Hidayat et al., 2020). Meta-analysis may also be applied to confirm quantitatively the nature of results within a body of research (Hooge and Conolly, 2011). Accordingly, the aim of the current study was to determine the effects of probiotics on the performance, egg quality and blood parameters of laying hens by using the meta-analysis of previously published articles.

\section{Material and methods}

\section{Development of database}

A database was constructed based on peerreviewed and published research articles which reported the use of probiotics in laying hens diet. The probiotics here are specifically for lactic acid bacteria, yeast and their combination. Articles were selected based on the Systematic Review Centre for Laboratory Animal Experimentation (SYRCLE) (de Vries et al., 2015) and Preferred Reporting Items for Systematic Review and Meta-Analyses (PRISMA) (Liberati et al., 2009) protocols. Articles were retrieved from PubMed, Web of Science, Scopus, Google Scholar and Science Direct databases as well as individual journals such as World Poultry Journal Science, British Poultry Science and
International Journal of Poultry Science using the key words: 'probiotic', 'laying hens', 'performance', 'egg quality' and/or 'blood serum'. Details for the selection process are provided in Figure 1.

\section{Identification}

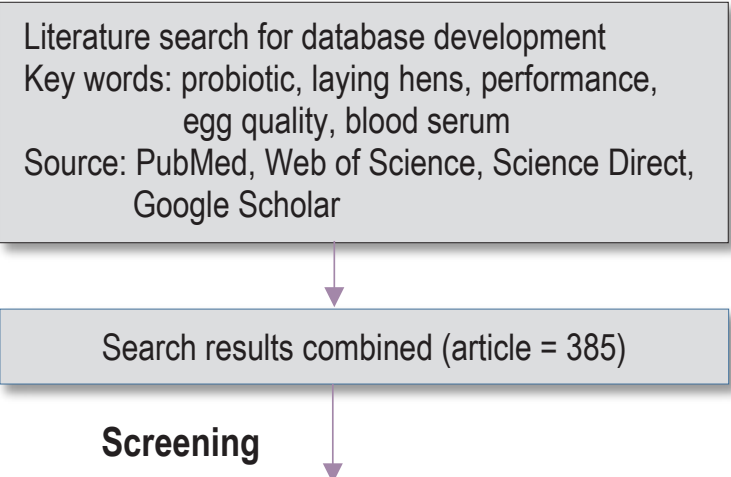

Articles screened on basis SYRCLE method

Non-relevant criteria

Non-relevant parameters: article $=34$

Non-relevant probiotic microorganism: article $=42$

Non-relevant animals: article $=56$

In vitro studies: article $=91$

Paper are not in covered year/too old: article $=102$
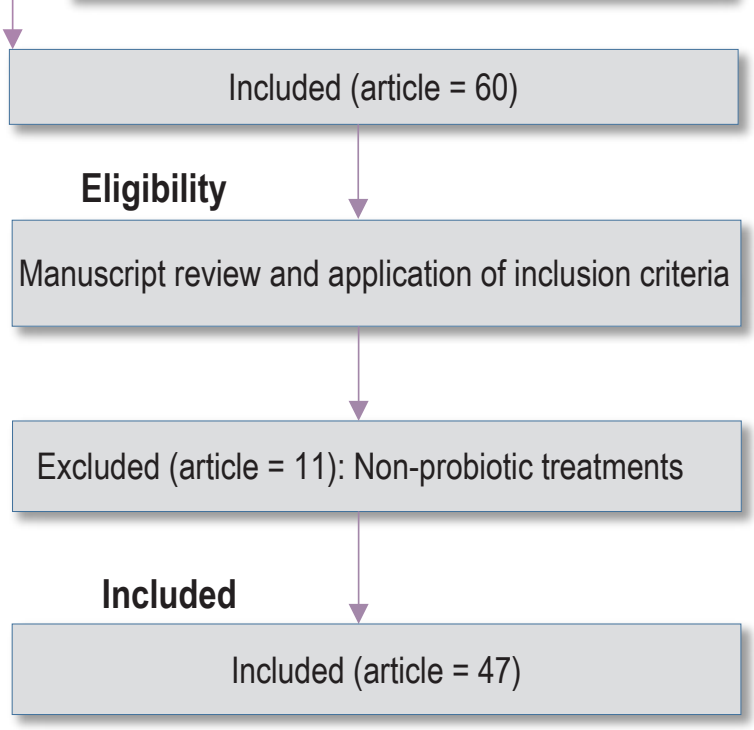

Figure 1. Diagram flow of article selection in the meta-analysis using Systematic Review Centre for Laboratory Animal Experimentation (SYRCLE) method

Criteria for an article to be included in the database were as follows: (a) the article is published in English in a peer-reviewed journal published between 2003 and 2020, (b) the experiment was performed in a controlled-trial environment, (c) the experiment was performed directly on laying hens in vivo as the experimental animals, (d) the 
concentrations of probiotic both in powder and liquid forms are provided in the methods section, allowing for calculation and transformation into a logarithmic unit, (e) in the experiment the information on the experimental period and specific ages of animals is provided, and (f) dosages of probiotics constituted $0-5 \mathrm{~g} / \mathrm{kg}$ of the formula. The final database consisted of 47 in vivo studies with
190 treatments. General information, details of treatment and variable outputs from these articles were summarized in a spreadsheet prior to analyses. When data were presented in graphical forms, the data were extracted by using WebPlotDigitizer in order to obtain the exact values (Drevon et al., 2017). The details of the studies included in the meta-analysis are summarized in Table 1.

Table 1. Studies included in the meta-analyses of the effect of probiotics on the performance, egg quality and blood parameters in laying hens

\begin{tabular}{|c|c|c|c|c|}
\hline References & Kind of probiotic & Form & Dosage, $\mathrm{g} / \mathrm{kg}$ & Periods, week \\
\hline Zhu et al. (2015) & lactic acid bacteria & powder & $0-0.1$ & $15-20$ \\
\hline Panda et al. (2008) & lactic acid bacteria & powder & $0-0.15$ & $25-40$ \\
\hline Afsari et al. (2014) & yeast & powder & $0-0.06$ & $56-64$ \\
\hline Mohebbifar et al. (2013) & lactic acid bacteria & powder & $0-0.1$ & $74-82$ \\
\hline Panda et al. (2003) & lactic acid bacteria & powder & $0-0.2$ & $24-64$ \\
\hline Sobczak and Kozłowski (2015) & lactic acid bacteria & powder & $0-0.14$ & $18-44$ \\
\hline Li et al. (2011) & lactic acid bacteria & powder & $0-0.1$ & $56-64$ \\
\hline Zhang and Kim (2013) & lactic acid bacteria & powder & $0-0.01$ & $15-40$ \\
\hline Baghban-Kanani et al. (2019) & lactic acid bacteria & powder & $0-0.1$ & $15-32$ \\
\hline Fathi et al. (2018) & lactic acid bacteria & powder & $0-0.4$ & $15-36$ \\
\hline Khan et al. (2011) & yeast & powder & $0-0.5$ & $20-40$ \\
\hline Hayirli et al. (2005) & lactic acid bacteria & powder & $0-0.3$ & 46 \\
\hline Kashani et al. (2013) & yeast & powder & $0-0.05$ & $80-87$ \\
\hline Asli et al. (2007) & combination & powder & $0-1$ & $40-62$ \\
\hline Pan et al. (2011) & lactic acid bacteria & powder & $0-0.15$ & 58 \\
\hline Kurtoglu et al. (2004) & lactic acid bacteria & powder & $0-0.75$ & $1-90$ \\
\hline Zhang et al. (2012) & lactic acid bacteria & powder & $0-0.06$ & 24 \\
\hline Arpášová et al. (2016) & lactic acid bacteria & powder & $0-0.5$ & 21 \\
\hline Mahdavi et al. (2005) & lactic acid bacteria & powder & $0-0.12$ & $28-39$ \\
\hline Forte et al. (2016) & lactic acid bacteria & powder & $0-0.05$ & 20 \\
\hline Mikulski et al. (2012) & lactic acid bacteria & powder & $0-0.05$ & $23-46$ \\
\hline Tang et al. (2015) & lactic acid bacteria & powder & $0-0.01$ & $20-36$ \\
\hline Tang et al. (2017) & lactic acid bacteria & powder & $0-1.01$ & $20-52$ \\
\hline Elnagar (2013) & yeast & powder & $0-0.6$ & 26 \\
\hline Abd Elhalim et al. (2007) & lactic acid bacteria & powder & $0-0.1$ & $39-47$ \\
\hline Hassan et al. (2019) & lactic acid bacteria & powder & $0-0.1$ & $29-50$ \\
\hline Abdel-Wareth (2016) & lactic acid bacteria & powder & $0-0.1$ & $24-36$ \\
\hline Fujiwara et al. (2008) & lactic acid bacteria & powder & $0-0.1$ & $15-29$ \\
\hline Loh et al. (2014) & lactic acid bacteria & liquid & $0-0.6$ & 23 \\
\hline Saleh et al. (2017) & lactic acid bacteria & powder & $0-0.05$ & $28-34$ \\
\hline Bonsu et al. (2014) & lactic acid bacteria & powder & $0-0.15$ & 22 \\
\hline Yalçın et al. (2012) & yeast & powder & $0-2$ & $18-23$ \\
\hline Behnamifar et al. (2015) & lactic acid bacteria & liquid & $0-1$ & 85 \\
\hline Lei et al. (2013) & lactic acid bacteria & powder & $0-0.09$ & 28 \\
\hline Yalçın et al. (2015) & yeast & powder & $0-0.5$ & 54 \\
\hline Aghaii et al. (2010) & lactic acid bacteria & powder & $0-0.2$ & $41-49$ \\
\hline Anwar and Rahman (2016) & lactic acid bacteria & liquid & $0-0.85$ & 70 \\
\hline Xiang et al. (2019) & yeast & powder & $0-0.15$ & $15-30$ \\
\hline Yalçın et al. (2014) & yeast & powder & $0-4$ & 26 \\
\hline Desoky and Kamel (2018) & yeast & powder & $0-0.125$ & $32-43$ \\
\hline Lee et al. (2019) & lactic acid bacteria & liquid & $0-0.1$ & 40 \\
\hline Mikulski et al. (2020) & lactic acid bacteria & powder & $0-0.1$ & $32-47$ \\
\hline Zhan et al. (2019) & lactic acid bacteria & powder & $0-0.2$ & $48-58$ \\
\hline Yalçın et al. (2010) & yeast & powder & $0-4$ & 22 \\
\hline Yalçın et al. (2008) & yeast & powder & $0-2.85$ & $16-21$ \\
\hline Al-Harthi (2015) & yeast & powder & $0-0.4$ & $48-56$ \\
\hline Sun et al. (2015) & yeast & powder & $0-5$ & $40-48$ \\
\hline
\end{tabular}




\section{Data analysis}

Analysis of the database was carried out according to the mixed-model methodology (St-Pierre, 2001; Sauvant et al., 2008; Patra, 2013), performed by using the R software version 3.6.30 with library 'nlme' (Pinheiro et al., 2020; R Core Team, 2020). The experiments were considered as the random effects while the probiotics concentrations were taken as the fixed effects, using the following mathematical model:

$$
\mathrm{Y}_{\mathrm{ij}}=\beta_{0}+\beta_{1} \text { Level }_{\mathrm{ij}}+\text { Experiment }_{\mathrm{i}}+\text { Experiment }_{\mathrm{i}} \times
$$

where: $\mathrm{Y}_{\mathrm{ij}}$ - dependent variable, $\beta_{0}$ - value when level intersects the $\mathrm{Y}$ axis for all random effect combinations, $\beta_{1}-$ coefficient level of order 1 , Level $_{\mathrm{ij}}$ - level addition of the probiotics (fixed effects), Experiment ${ }_{i}$ - number of trial-i (random effects), $e_{i j}$ - model error. Initially, the formula used was a quadratic model, but it was modified to the corresponding linear model as above since the quadratic model was insignificant.

\section{Results}

Dietary addition of probiotics increased $(P<0.001)$ egg production and decreased $(P<0.01)$ feed egg ratio (FER) (Table 2). Egg mass and feed intake were not affected by the addition of probiotics. With regard to egg quality parameters, probiotics did not affect egg weight but increased eggshell thickness $(P<0.001)$, eggshell weight $(P<0.01)$ and yolk colour $(P<0.01)$. Haugh unit tended to increase $(P<0.1)$ whereas the egg index tended to decrease $(P<0.1)$ by probiotic addition. Probiotics reduced $(P<0.05)$ blood cholesterol and low-density lipoprotein cholesterol (LDL-C) while elevated $(P<0.05)$ blood high-density lipoprotein cholesterol (HDL-C) concentrations in laying hens.

\section{Discussion}

The present study confirmed that the application of probiotics improved laying hens' productive performance as evidenced by the increasing egg production and feed efficiency. A number of scientific reports in the last few years have provided strong pieces of evidence explaining the role of probiotics in enhancing poultry production including broiler chickens and laying hens which could be connected with the current finding. For instance, Mikulski et al. (2020) reported that the use of Pediococcus acidilactici probiotics increased laying rate and feed efficiency by approximately $2.8 \%$. They also demonstrated that probiotics could successfully compensate low apparent metabolizable energy (AME) diet by maintaining productive performance. Studies on other probiotics strains such as Bacillus subtillis, Enterococcus faecium, Lactobacillus and yeasts also demonstrated similar amelioration in production traits of laying hens (Mikulski et al., 2012; Zhang and Kim, 2013; Park et al., 2016a; Wang et al., 2020).

These improvements are mainly associated with increasing nutrient use efficiency as a result of the role of probiotics in many biological pathways. There is a general convention that probiotics can effectively enhance the morphology of intestinal epithelial cells and their barrier system, digestive enzyme secretion and favourable microorganisms (Ding et al., 2020). From this point, further beneficial effects are explained such as immune system

\begin{tabular}{|c|c|c|c|c|c|c|c|c|c|c|c|}
\hline \multirow{2}{*}{ Indices } & \multirow{2}{*}{ Unit } & \multirow{2}{*}{$M$} & \multirow{2}{*}{$\mathrm{N}$} & \multicolumn{4}{|c|}{ Parameter estimates } & \multicolumn{3}{|c|}{ Model estimates } & \multirow{2}{*}{$\begin{array}{l}\text { Interpretation } \\
\text { trend }\end{array}$} \\
\hline & & & & intercept & SE intercept & slope & SE slope & $P$-value & RMSE & AIC & \\
\hline Egg production & $\%$ & $L$ & 190 & 84.63 & 1.263 & 0.156 & 0.0363 & $<0.001$ & 1.914 & 975 & positive \\
\hline Egg mass & g/hen/day & $L$ & 190 & 53.05 & 0.972 & 0.033 & 0.0664 & 0.612 & 4.246 & 1.112 & positive \\
\hline FER & $\mathrm{g}$ feed/g egg & $\mathrm{L}$ & 190 & 2.14 & 0.051 & -0.005 & 0.0018 & 0.008 & 2.249 & -170.46 & negative \\
\hline Feed intake & g/hen/day & $\mathrm{L}$ & 190 & 118.7 & 11.36 & 0.520 & 1.746 & 0.766 & 5.97 & 2.236 & positive \\
\hline Egg weight & $g$ & L & 190 & 60.11 & 0.732 & 0.018 & 0.0327 & 0.570 & 3.64 & 891.25 & positive \\
\hline Egg shell thickness & $\mathrm{mm}$ & L & 190 & 0.37 & 0.015 & 0.0012 & 0.0004 & $<0.001$ & 3.50 & -738.80 & positive \\
\hline Egg shell weight & g & $L$ & 190 & 5.01 & 0.245 & 0.0133 & 0.0044 & 0.003 & 2.80 & 229.00 & positive \\
\hline Yolk colour & roche & L & 190 & 7.22 & 0.276 & 0.015 & 0.0056 & 0.007 & 2.13 & 308.49 & positive \\
\hline Haugh unit & no unit & $\mathrm{L}$ & 190 & 80.00 & 1.600 & 0.010 & 0.050 & 0.067 & 1.94 & 1.082 & positive \\
\hline Egg index & no unit & $\mathrm{L}$ & 190 & 0.92 & 0.04 & -0.002 & 0.0012 & 0.076 & 4.21 & -297 & negative \\
\hline Cholesterol & $\mathrm{mmol} / \mathrm{l}$ & $L$ & 189 & 1.70 & 0.115 & -0.011 & 0.005 & 0.030 & 3.70 & 192.37 & negative \\
\hline HDL-C & $\mathrm{mmol} / \mathrm{l}$ & L & 189 & 40.31 & 2.044 & 0.1277 & 0.062 & 0.042 & 3.00 & 1.165 & positive \\
\hline LDL-C & $\mathrm{mmol} / \mathrm{l}$ & $\mathrm{L}$ & 189 & 130.00 & 4.86 & -0.400 & 0.202 & 0.050 & 2.07 & 1.574 & negative \\
\hline
\end{tabular}

Table 2. Regression linear model of the effect of probiotics on the laying hen performance, egg quality and blood parameters

M - model; $\mathrm{N}$ - number of data; SE - standard error; RMSE - root mean square errors; AIC - akaike information criterion; FER - feed egg ratio; L - linear; HDL - high-density lipoprotein cholesterol; LDL-C - low-density lipoprotein cholesterol 
improvement (Deng et al., 2012; Rehman et al., 2020). Specifically, some mechanisms of nutrient absorption in laying hens during probiotics supplementation will be described.

First, it can be attributed to the higher enzyme secretion that is positively associated with increasing digestion and nutrient absorption. This was in line with studies by Zhang and Kim (2013) and Park et al. (2016b) who found that probiotics increased nitrogen and energy utilization. Increasing nitrogen digestibility is beneficial to lesser fermentable substrates available for pathogens in the intestine which also contributed to improve microbial balance and gut health as well as to reduce ammonia secretion to the environment (Zhang and Kim, 2013).

Secondly, probiotics have been reported to increase bone mineralization by increasing the calcium (Ca) and phosphorus (P) absorption (Yan et al., 2019). It makes sense when eggshell thickness and eggshell weight increased in the present meta-analysis because probiotics are able to promote an acidic $\mathrm{pH}$ in the intestinal tract due to antibacterial, organic acids and volatile fatty acids production (Al-Khalaifa et al., 2019). Probiotics are not only effective to increase minerals absorption but also inhibit pathogenic growth (Ding et al., 2020). In their fermentation pathway, probiotics produce organic acids such as butyric acid as a major end-product. Butyrate is an important source of energy for intestinal epithelial cells that can inhibit inflammation, enhance the barrier function for pathogenic defence, and reduce oxidative stress (Guo et al., 2020; Tang et al., 2020). Animal well-being is an important physiological condition to support optimal metabolism and production (Sjofjan et al., 2021).

Furthermore, we have also notice an increase in yolk colour of the egg. Similar results were reported by Sobczak and Kozłowski (2015) and Neijat et al. (2019) who found an improvement in the interior quality of eggs such as yolk colour, Haugh unit, and weights of yolk and albumin in laying hens receiving Bacillus subtilis at the age of 18-42 weeks. Increasing nitrogen utilization and improving the gut environment might possibly explain the reason of beneficial effect of probiotics. Thinning of albumen as a result of increased protein transfer rate is associated with the increase of Haugh unit (Lei et al., 2013). In addition, decreasing intestinal $\mathrm{pH}$ and improving caution solubility which favour gut environment to increase mineral absorption are also connected with the enhancement of interior and exterior egg quality parameters (Behnamifar et al., 2015; Neijat et al., 2019).
In regard to eggshell thickness and weight, it was reported that probiotics increased eggshell thickness and weight when fed to laying hens at the age of 28-32 and 32-36 weeks as well as at late production phase (72 to 79 weeks of age), respectively (Fujiwara et al., 2008; Behnamifar et al., 2015; Wang et al., 2020). Fujiwara et al. (2008) suggested that eggshell parameters were equally influenced by the metabolic activity of beneficial bacterial colonies, which could positively influence the absorption rate of calcium $\left(\mathrm{Ca}^{2+}\right)$ and magnesium $\left(\mathrm{Mg}^{2+}\right)$. This was also beneficial to increase the egg weight and its interior quality (Lei et al., 2013). However, it should be noted that the microbial strains used as probiotics may have different effects. For example, Loh et al. (2014) reported that Lactobacillus plantarum probiotics supplementation had no effect on egg weight.

It was stated that in laying hens probiotics reduced cholesterol and LDL-C while elevated HDL-C blood concentrations. Zhang et al. (2012) suggested that it might be related to the activity of the microorganisms in recycling lipids in the intestine of laying hens. Some LAB, such as Bacillus subtilis, were reported to prevent bile salts re-absorption and to increase their extraction with faeces. Simultaneously the probiotic-derived cholesterol blood concentration reduction can be connected with inhibited synthesis of enzymes participating in the cholesterol synthesis, increased cholesterol excretion with the faeces and increased utilization of circulation cholesterol for the synthesis of the bacterial cell wall (Loh et al., 2014).

\section{Conclusions}

The present meta-analysis confirms that probiotics supplementation increases egg production of laying hens and alters eggs interior and exterior qualities such as Haugh unit, yolk colour, eggshell thickness and eggshell weight. Probiotics are also effective to decrease low-density lipoprotein cholesterol while increasing high-density lipoprotein cholesterol blood concentrations, so can increase health-promoting properties of poultry products. However, bacterial strains may result differently and therefore future studies in this area are needed.

\section{Acknowledgements}

The authors are grateful to Animal Feed and Nutrition Modelling (AFENUE) Research Group, IPB University (Bogor, Indonesia) for technically supporting the present study. 


\section{Conflict of interest}

The authors declare that there is no conflict of interest.

\section{References}

Abd Elhalim H.S., Attia F.A.M., Hanafy A.M., Khalil H.A., 2007. Effects of probiotic (Biogen) and zinc bacitracin supplementation on laying hen performance, some blood parameters and egg quality. Agric. Res. J. 7, 11-19

Abd El-Hack M.E., Mahgoub S.A., Alagawany M., Ashour E.A., 2017. Improving productive performance and mitigating harmful emissions from laying hen excreta via feeding on graded levels of corn DDGS with or without Bacillus subtilis probiotic. J. Anim. Physiol. Anim. Nutr. 101, 904-913, https://doi. org/10.1111/jpn.12522

Abdel-Wareth A.A.A., 2016. Effect of dietary supplementation of thy$\mathrm{mol}$, synbiotic and their combination on performance, egg quality and serum metabolic profile of Hy-Line Brown hens. Br. Poult. Sci. 57, 114-122, https://doi.org/10.1080/0007166 8.2015.1123219

Afsari M., Mohebbifar A., Torki M., 2014. Effects of dietary inclusion of olive pulp supplemented with probiotics on productive performance, egg quality and blood parameters of laying hens. Ann. Res. Rev. Biol. 4, 198-211, https://doi.org/10.9734/ ARRB/2014/5212

Aghaii A., Chaji M., Mohammadabadi T., Sari M., 2010. The effect of probiotic supplementation on production performance, egg quality and serum and egg chemical composition of lying hens. J. Anim. Vet. Adv. 9, 2774-2777, https://doi. org/10.3923/javaa.2010.2774.2777

Al-Harthi M.A., 2015. The effect of different dietary contents of olive cake with or without Saccharomyces cerevisiae on egg production and quality, inner organs and blood constituents of commercial layers. Eur. Poult. Sci. 79, 1-14, https://doi. org/10.4081/ijas.2015.3966

Al-Khalaifa H., Al-Nasser A., Al-Surayee T., Al-Kandari S., Al-Enzi N., Al-Sharrah T., Ragheb G., Al-Qalaf S., Mohammed A., 2019. Effect of dietary probiotics and prebiotics on the performance of broiler chickens. Poult. Sci. 98, 4465-4479, https://doi. org/10.3382/ps/pez282

Anwar H., Rahman Z.U., 2016. Efficacy of protein, symbiotic and probiotic supplementation on production performance and egg quality characteristics in molted layers. Trop. Anim. Health Prod. 48, 1361-1367, https://doi.org/10.1007/s11250-0161093-7

Arpášová H., Kačániová M., Pistová V., Gálik B., Fik M., Hleba L., 2016. Effect of probiotics and humic acid on egg production and quality parameters of laying hens eggs. Sci. Pap. Anim. Sci. Biotechnol. 49, 1-9

Asli M.M., Shariatmadari F., Hosseini S.A., Lotfollahian H., 2007. Effect of probiotics, yeast, vitamin $\mathrm{E}$ and vitamin $\mathrm{C}$ supplements on performance and immune response of laying hen during high environmental temperature. Int. J. Poult. Sci. 6, 895-900, https://doi.org/10.3923/ijps.2007.895.900

Baghban-Kanani P., Hosseintabar-Ghasemabad B., Azimi-Youvalari S., Seidavi A., Ragni M., Laudadio V., Tufarelli V., 2019. Effects of using Artemisia annua leaves, probiotic blend, and organic acids on performance, egg quality, blood biochemistry, and antioxidant status of laying hens. J. Poult. Sci. 56, 120-127, https://doi.org/10.2141/jpsa.018005
Behnamifar A., Rahimi S., Torshizi M.A.K., 2015. Effect of probiotic, thyme, garlic and caraway herbal extracts on the quality and quantity of eggs, blood parameters, intestinal bacterial population and histomorphology in laying hens. J. Med. Plants By-product 4, 121-128, https://doi.org/10.22092/ JMPB.2015.108899

Bonsu F.R.K., Donkoh A., Osei S.A., Okai D.B., Baah J., 2014. Directfed microbial on the health status, productive performance and internal egg characteristics of layer chickens under hot humid environmental conditions. Afr. J. Agric. Res. 9, 14-20, https://doi.org/10.5897/AJAR2013.7748

de Vries R.B.M., Hooijmans C.R., Langendam M.W., van Luijk J., Leenaars M., Ritskes-Hoitinga M., Wever K.E., 2015. A protocol format for the preparation, registration and publication of systematic reviews of animal intervention studies. Evid. Based Preclin. Med. 2, e00007, https://doi.org/10.1002/ebm2.7

Deng W., Dong X.F., Tong J.M., Zhang Q., 2012. The probiotic Bacillus licheniformis ameliorates heat stress-induced impairment of egg production, gut morphology, and intestinal mucosal immunity in laying hens. Poult. Sci. 91, 575-582, https://doi. org/10.3382/ps.2010-01293

Desoky A.A.E., Kamel N.N., 2018. Effects of yeast and vitamin C supplementation on egg production, egg quality, antibody titer and intestine microbial burden of Hy-Line Brown hens under summer conditions. Egypt. Poult. Sci. J. 38, 593-605

Ding S., Yan W., Ma Y., Fang, J., 2020. The impact of probiotics on gut health via alternation of immune status of monogastric animals. Anim. Nutr. in press (available online 26 December 2020), https://doi.org/10.1016/j.aninu.2020.11.004

Drevon D., Fursa S.R., Malcolm A.L., 2017. Intercoder reliability and validity of WebPlotDigitizer in extracting graphed data. Behav. Modif. 41, 323-339, https://doi. org/10.1177/0145445516673998

Elnagar S.H.M., 2013. Effect of dried yeast (Saccharomyces cerevisiae) supplementation as feed additive to laying hen diet on egg production, egg quality, carcass traits and blood constituents. Egypt. J. Anim. Prod. 50, 111-115, https://doi.org/10.21608/ ejap.2013.94307

Fathi M., Al-Homidan I., Al-Dokhail A., Ebeid T., Abou-Emera O., Alsagan A., 2018. Effects of dietary probiotic (Bacillus subtilis) supplementation on productive performance, immune response and egg quality characteristics in laying hens under high ambient temperature. Ital. J. Anim. Sci. 17, 804-814, https://doi.org/10.1080/1828051X.2018.1425104

Fujiwara K., Miyaguchi Y., Toyoda A., Nakamura Y., Yamazaki M., Nakashima K., Abe H., 2008. Effect of fermented soybean 'natto' supplement on egg production and qualities. Asian-Australas. J. Anim. Sci. 21, 1610-1615, https://doi.org/10.5713/ ajas. 2008.70654

Forte C., Moscati L., Acuti G., Mugnai C., Franciosini M.P., Costarelli S., Cobellis G., Trabalza-Marinucci M., 2016. Effects of dietary Lactobacillus acidophilus and Bacillus subtilis on laying performance, egg quality, blood biochemistry and immune response of organic laying hens. J. Anim. Physiol. Anim. Nutr 100, 977-987, https://doi.org/10.1111/jpn.12408

Guo Q., Li F., Duan Y., Wen C., Wang W., Zhang L., Huang R., Yin Y., 2020. Oxidative stress, nutritional antioxidants and beyond Sci. China Life Sci. 63, 866-874, https://doi.org/10.1007/ s11427-019-9591-5

Hassan M.R., Sultana S., Al Rahman M.O., Rabbani M.A.G., Sarker N.R., Ju Y.C., Ryu K.S., 2019. Effect of feeding various probiotics on performance, blood properties, egg quality, and yolk fatty acid composition of laying hens. Aust. J. Sci. Technol. 3, 43-47 
Hayirli A., Esenbuğa N., Macit M., Yörük M.A., Yıldız A., Karaca H., 2005. Nutrition practice to alleviate the adverse effects of stress on laying performance, metabolic profile and egg quality in peak producing hens: II. The probiotic supplementation. Asian-Australas. J. Anim. Sci. 18, 1752-1760, https://doi. org/10.5713/ajas.2005.1752

Hidayat C., Sumiati, Jayanegara A., Wina E., 2020. Effect of zinc on the immune response and production performance of broilers: a meta-analysis. Asian-Australas. J. Anim. Sci. 33, 465-479, https://doi.org/10.5713/ajas.19.0146

Hooge M.D., Connolly A., 2011. Meta-Analysis summary of broiler chicken trials with dietary Actigen ${ }^{\circledR}$ (2009-2011). Int. J. Poult. Sci. 10, 819-824, https://doi.org/10.3923/ijps.2011.819.824

Kashani S., Mohebbifar A., Habibian M., Torki M., 2013. Effects of dietary inclusion of ground pits of date palm (Phoenix dactylifera) with or without probiotic yeasture ${ }^{\circledR}$ on productive performance, egg traits and some blood parameters of laying hens. Ann. Res. Rev. Biol. 3, 492-506

Khan S.H., Atif M., Mukhtar N., Rehman A., Fareed G., 2011. Effects of supplementation of multi-enzyme and multi-species probiotic on production performance, egg quality, cholesterol level and immune system in laying hens. J. Appl. Anim. Res. 39, 386-398, https://doi.org/10.1080/09712119.2011.621538

Kurtoglu V., Kurtoglu F., Seker E., Coskun B., Balevi T., Polat E.S., 2004. Effect of probiotic supplementation on laying hen diets on yield performance and serum and egg yolk cholesterol. Food Add. Contam. 21, 817-823, https://doi.org/10.1080/02 652030310001639530

Lee A.R., Niu K.M., Lee W.D., Kothari D., Kim S.K., 2019. Comparison of the dietary supplementation of Lactobacillus plantarum, and fermented and non-fermented Artemisia annua on the performance, egg quality, serum cholesterol, and eggyolkoxidative stability during storage in laying hens. Braz. J. Poult. Sci. 21, eRBCA-2018-0903, https://doi.org/10.1590/18069061-2018-0903

Liberati A., Altman D.G., Tetzlaff J., Mulrow C., Gøtzsche P.C., loannidis J.P., Clarke M., Devereaux P.J., Kleijnen J., Moher D., 2009. The PRISMA statement for reporting systematic reviews and meta-analyses of studies that evaluate health care interventions: explanation and elaboration. BMJ 339 , b2700, https://doi.org/10.1136/bmj.b2700

Lei K., Li Y.L., Yu D.Y., Rajput I.R., Li W.F., 2013. Influence of dietary inclusion of Bacillus licheniformis on laying performance, egg quality, antioxidant enzyme activities, and intestinal barrier function of laying hens. Poult. Sci. 92, 2389-2395, https://doi. org/10.3382/ps.2012-02686

Li W.F., Rajput I.R., Xu X., Li Y.L., Lei J., Huang Q., Wang M.Q., 2011. Effects of probiotic (Bacillus subtilis) on laying performance, blood biochemical properties and intestinal microflora of laying hens. Int. J. Poult. Sci. 10, 583-589, https://doi.org/10.3923/ ijps.2011.583.589

Loh T.C., Choe D.W., Foo H.L., Sazili A.Q., Bejo M.H., 2014. Effects of feeding different post biotic metabolite combinations produced by Lactobacillus plantarum strains on egg quality and production performance, faecal parameters and plasma cholesterol in laying hens. BMC Vet. Res. 10, 149, https://doi. org/10.1186/1746-6148-10-149

Mahdavi A.H., Rahmani H.R., Pourreza J., 2005. Effect of probiotic inclusion in different levels of barley substitution for corn diets on laying hen's histological changes of duodenum. In: Proceedings of WPSA, 15th European Symposium on Poultry Nutrition. 25-29 September 2005, Balatonfüred (Hungary), pp. 321-323

Markowiak P., Śliżewska K., 2018. The role of probiotics, prebiotics and synbiotics in animal nutrition. Gut Pathog. 10, 21, https:// doi.org/10.1186/s13099-018-0250-0
Maron D.F., Smith T.J.S., Nachman K.E., 2013. Restrictions on antimicrobial use in food animal production: an international regulatory and economic survey. Glob. Health 9, 48, https://doi. org/10.1186/1744-8603-9-48

Mikulski D., Jankowski J., Mikulska M., Demey V., 2020. Effects of dietary probiotic (Pediococcus acidilactici) supplementation on productive performance, egg quality, and body composition in laying hens fed diets varying in energy density. Poult. Sci. 99, 2275-2285, https://doi.org/10.1016/j.psj.2019.11.046

Mikulski D., Jankowski J., Naczmanski J., Mikulska M., Demey V., 2012. Effects of dietary probiotic (Pediococcus acidilactici) supplementation on performance, nutrient digestibility, egg traits, egg yolk cholesterol, and fatty acid profile in laying hens. Poult. Sci. 91, 2691-2700, https://doi.org/10.3382/ ps.2012-02370

Mohebbifar A., Kashani S., Afsari M., Torki M., 2013. Effects of commercial prebiotic and probiotics of diet on performance of laying hens, egg traits and some blood parameters. Ann. Rev. Res. Biol. 3, 921-934

Neijat M., Shirley R.B., Barton J., Thiery P., Welsher A., Kiarie E., 2019. Effect of dietary supplementation of Bacillus subtilis DSM29784 on hen performance, egg quality indices, and apparent retention of dietary components in laying hens from 19 to 48 weeks of age. Poult. Sci. 98, 5622-5635, https://doi. org/10.3382/ps/pez324

Pan C., Zhao Y., Liao S.F., Chen F., Qin S., Wu X., Zhou H., Huang K., 2011. Effect of selenium-enriched probiotics on laying performance, egg quality, egg selenium content, and egg glutathione peroxidase activity. J. Agric. Food Chem. 59, 11424-11431, https://doi.org/10.1021/jf202014k

Panda A.K., Rama Rao S.S., Raju M.V.L.N., Sharma S.S., 2008. Effect of probiotic (Lactobacillus sporogenes) feeding on egg production and quality, yolk cholesterol and humoral immune response of white leghorn layer breeders. J. Sci. Food Agric. 88, 43-47, https://doi.org/10.1002/jsfa.2921

Panda A.K., Reddy M.R., Rama Rao S.V., Praharaj N.K., 2003. Production performance, serum/yolk cholesterol and immune competence of white leghorn layers as influenced by dietary supplementation with probiotic. Trop. Anim. Health Prod. 35, 85-94, https://doi.org/10.1023/A:1022036023325

Park Y.H., Hamidon F., Rajangan C., Soh K.P., Gan C.Y., Lim T.S., Abdullah W.N.W., Liong M.T., 2016a. Application of probiotics for the production of safe and high-quality poultry meat. Korean J. Food Sci. Anim. Resour. 36, 567-576, https://doi. org/10.5851/kosfa.2016.36.5.567

Park J.W., Jeong J.S., Lee S.I., Kim I.H., 2016b. Effect of dietary supplementation with a probiotic (Enterococcus faecium) on production performance, excreta microflora, ammonia emission, and nutrient utilization in ISA brown laying hens. Poult. Sci. 95, 2829-2835, https://doi.org/10.3382/ps/pew241

Patra A.K., 2013. The effect of dietary fats on methane emissions, and its other effects on digestibility, rumen fermentation and lactation performance in cattle: a meta-analysis. Livest. Sci. 155, 244-254, https://doi.org/10.1016/j.livsci.2013.05.023

Pinheiro J., Bates D., DebRoy S. et al., 2020. nIme: Linear and Nonlinear Mixed Effects Models. https://cran.r-project.org/web/ packages/nlme

R Core Team, 2020. R: A Language and Environment for Statistical Computing. R Foundation for Statistical Computing. Vienna (Austria), http://www.r-project.org/index.html

Rehman A., Arif M., Sajjad N. et al., 2020. Dietary effect of probiotics and prebiotics on broiler performance, carcass, and immunity. Poult. Sci. 99, 6946-6953, https://doi.org/10.1016/j. psj.2020.09.043 
Saleh A.A., Gálik B., Arpášová H., Capcarová M., Kalafová A., Šimko M., Juráček M., Rolinec M., Bíro D., Abudabos A.M., 2017. Synergistic effect of feeding Aspergillus awamori and lactic acid bacteria on performance, egg traits, egg yolk cholesterol and fatty acid profile in laying hens. Ital. J. Anim. Sci. 16, 132-139, https://doi.org/10.1080/1828051X.2016.1269300

Sauvant D., Schmidely P., Daudin J.J., St-Pierre N.R., 2008. Metaanalyses of experimental data in animal nutrition. Animal 2, 1203-1214, https://doi.org/10.1017/S1751731108002280

Sjofjan O., Adli D.N., Natsir M.H., Nuningtyas Y.F., Bastomi I., Amalia F.R., 2021. The effect of increasing levels of palm kernel meal containing $\alpha-\beta$-mannanase replacing maize to growing-finishing hybrid duck on growth performance, nutrient digestibility, carcass trait, and VFA. J. Indonesian Trop. Anim. Agric. 46, 29-39, https://doi.org/10.14710/jitaa.46.1.29-39

Sobczak A., Kozłowski K., 2015. The effect of a probiotic preparation containing Bacillus subtilis ATCC PTA-6737 on egg production and physiological parameters of laying hens. Ann. Anim. Sci. 15, 711-723, https://doi.org/10.1515/aoas-2015-0040

St-Pierre N.R., 2001. Integrating quantitative findings from multiple studies using mixed model methodology. J. Dairy Sci. 84, 741-755, https://doi.org/10.3168/jds.S0022-0302(01)74530-4

Sun H., Wu. Y., Wang X., Liu Y., Yao X., Tang J., 2015. Effects of dietary supplementation with red yeast rice on laying performance, egg quality and serum traits of laying hens. Ital. J. Anim. Sci. 14, 4059, https://doi.org/10.4081/ijas.2015.4059

Tang S.G.H., Sieo C.C., Kalavathy R., Saad W.Z., Wong H.K., Ho Y.W., 2017. Performance, biochemical and haematological responses, and relative organ weights of laying hens fed diets supplemented with prebiotic, probiotic and synbiotic. BMC Vet. Res. 13, 248, https://doi.org/10.1186/s12917-0171160-y

Tang S.G.H., Sieo C.C., Kalavathy R., Saad W.Z., Yong S.T., Wong H.K., Ho Y.W., 2015. Chemical compositions of egg yolks and egg quality of laying hens fed prebiotic, probiotic, and synbiotic diets. J. Food Sci. 80, C1686-C1695, https://doi. org/10.1111/1750-3841.12947

Tang W., Wu J., Jin S. et al., 2020. Glutamate and aspartate alleviate testicular/ epididymal oxidative stress by supporting antioxidant enzymes and immune defense in boars. Sci. China Life Sci. 63, 116-124, https://doi.org/10.1007/s11427-018-9492-8

Wang J., Wang W.-w., Qi G.-h., Cui C.-f., Wu S.-g., Zhang H.-j., Xu L., Wang J., 2020. Effects of dietary Bacillus subtilis supplementation and calcium levels on performance and eggshell quality of laying hens in the late phase of production. Poult. Sci. in press (Available online 30 December 2020), https://doi. org/10.1016/j.psj.2020.12.067

Xiang Q., Wang C., Zhang H., Lai W., Wei H., Peng J., 2019. Effects of different probiotics on laying performance, egg quality, oxidative status, and gut health in laying hens. Animal 9, 1110, https://doi.org/10.3390/ani9121110

Yalçin S., Özsoy B., Erol H., Yalçin S., 2008. Yeast culture supplementation to laying hen diets containing soybean meal or sunflower seed meal and its effect on performance, egg quality traits, and blood chemistry. J. Appl. Poult. Res. 17, 229-236, https:/l doi.org/10.3382/japr.2007-00064
Yalçın S., Yalçin S., Çakın K., Eltan Ö., Dağaşan L., 2010. Effects of dietary yeast autolysate (Saccharomyces cerevisiae) on performance, egg traits, egg cholesterol content, egg yolk fatty acid composition and humoral immune response of laying hens. J. Sci. Food Agric. 90, 1695-1701, https://doi. org/10.1002/jsfa.4004

Yalçın S., Yalçın S., Onbaşilar İ., Eser H., Şahin A., 2014. Effects of dietary yeast cell wall on performance, egg quality and humoral immune response in laying hens. Ankara Üniv. Vet. Fak. Derg. 61, 289-294, https://doi.org/10.1501/Vetfak_0000002644

Yalçin S., Yalçin S., Şahin A., Duyum H.M., Çalik A., Gümüş H., 2015. Effects of dietary inactive yeast and live yeast on performance, egg quality traits, some blood parameters and antibody production to SRBC of laying hens. Kafkas Univ. Vet. Fak. Derg. 21, 345-350, https://doi.org/10.9775/ kvfd.2014.12493

Yalçın S., Yalçın S., Uzunoğlu K., Duyum H.M., Eltan Ö., 2012. Effects of dietary yeast autolysate (Saccharomyces cerevisiae) and black cumin seed (Nigella sativa L.) on performance, egg traits, some blood characteristics and antibody production of laying hens. Livest. Sci. 145, 13-20, https://doi.org/10.1016/j. livsci.2011.12.013

Yan F.F., Murugesan G.R., Cheng H.W., 2019. Effects of probiotic supplementation on performance traits, bone mineralization, cecal microbial composition, cytokines and corticosterone in laying hens. Animal 13, 33-41, https://doi.org/10.1017/ S175173111800109X

Yörük M.A., Gül M., Hayirli A., Macit M., 2004. The effects of supplementation of humate and probiotic on egg production and quality parameters during the late laying period in hens. Poult. Sci. 83, 84-88, https://doi.org/10.1093/ps/83.1.84

Zhan H.Q., Dong X.Y., Li L.L., Zheng Y.X., Gong Y.J., Zou X.T., 2019 Effects of dietary supplementation with Clostridium butyricum on laying performance, egg quality, serum parameters, and cecal microflora of laying hens in the late phase of production. Poult. Sci. 98, 896-903, https://doi.org/10.3382/ps/pey436

Zhang J.L., Xie Q.M., Ji J., Yang W.H., Wu Y.B., Li C., Ma J.Y., Bi Y.Z., 2012. Different combinations of probiotics improve the production performance, egg quality, and immune response of layer hens. Poult. Sci. 91, 2755-2760, https://doi. org/10.3382/ps.2012-02339

Zhang Z.F., Kim I.H., 2013. Effects of probiotic supplementation in different energy and nutrient density diets on performance, egg quality, excreta microflora, excreta noxious gas emission, and serum cholesterol concentrations in laying hens. J. Anim. Sci. 91, 4781-4787, https://doi.org/10.2527/jas.2013-6484

Zhu Y.Z., Cheng J.L., Ren M., Yin L., Piao X.S., 2015. Effect of -aminobutyric acid-producing Lactobacillus strain on laying performance, egg quality and serum enzyme activity in Hyline brown hens under heat stress. Asian-Australas. J. Anim. Sci. 28, 1006-1013, https://doi.org/10.5713/ajas.15.0119 